\title{
Строение кембрийских отложений вилюйской гемисинеклизы по результатам комплексного анализа данных бурения и сейсморазведки
}

Губин И. А., Конторович А. Э., Коровников И. В., Парфенова Т. М.

\begin{abstract}
Аннотация
В статье представлена модель стратиграфического и латерального распространения кембрийских отложений на территории Вилюйской гемисинеклизы, которая построена на основании анализа данных по бурению и интерпретации сейсмических данных. На отдельных участках изучаемой территории показан набор свит, толщ, вскрытых скважинами (Сюгджерская седловина, Хоргочумская моноклиналь, Ыгыаттинская впадина, Тюкян-Чыбыдинская моноклиналь, Арбайско-Синский мегавал и др.). На тех участках, где кембрий скважинами не вскрыт, выделены зоны распространения кембрийских отложений, прогнозируемые по сейсмическим данным и предполагаемые.
\end{abstract}

Подробно охарактеризовано распространение куонамского горизонта, состоящего из кембрийских пород, обогащенных органическим веществом. Это кумахская и синско-куторгиновая толщи, иниканская и куонамская свиты. По времени формирования куонамский горизонт разделен на два этапа: первый - соответствует ботомскому веку, второй - тойонскому и началу майского веков. Куонамский горизонт перекрыт более молодыми отложениями майского яруса, имеющими косослоистое строение.

В результате исследований построены схемы фациального районирования кембрийских отложений на ботомское, тойонско-раннемайское и среднемайское время с детальностью, отвечающей современному уровню геолого-геофизической изученности Вилюйской гемисинеклизы.

\section{Ключевые слова:}

Вилюйская гемисинеклиза, куонамская свита, иниканская свита, данные бурения, кембрий, временной разрез, сейсмофациальный анализ, рифогенные постройки. 


\title{
СТРОЕНИЕ КЕМБРИЙСКИХ ОТЛОЖЕНИЙ \\ ВИЛЮЙСКОЙ ГЕМИСИНЕКЛИЗЫ ПО РЕЗУЛЬТАТАМ КОМПЛЕКСНОГО АНАЛИЗА ДАННЫХ БУРЕНИЯ И СЕЙСМОРАЗВЕДКИ
}

\author{
И.А. Губин ${ }^{1}$, А.Э. Конторович ${ }^{1}$, И.В. Коровников ${ }^{1,2}$, Т.М. Парфенова ${ }^{1,2}$ \\ ${ }^{1}$ Институт нефтегазовой геологии и геофизики им. А.А. Трофимука СО РАН, \\ 630090, Новосибирск, просп. Коптюга, 3, Россия; \\ ${ }^{2}$ Новосибирский государственный университет, 630090, Новосибирск, ул. \\ Пирогова, 1, Россия \\ KorovnikovIV@ipgg.sbras.ru, GubinIA@ipgg.sbras.ru, KontorovichAE@ipgg.sbras.ru,
} ParfenovaTM@ipgg.sbras.ru

В статье представлена модель стратиграфического и латерального распространения кембрийских отложений на территории Вилюйской гемисинеклизы, которая построена на основании анализа данных по бурению и интерпретации сейсмических данных. На отдельных участках изучаемой территории показан набор свит, толщ, вскрытых скважинами (Сюгджерская седловина, Хоргочумская моноклиналь, Ыгыаттинская впадина, Тюкян-Чыбыдинская моноклиналь, Арбайско-Синский мегавал и др.). На тех участках, где кембрий скважинами не вскрыт, выделены зоны распространения кембрийских отложений, прогнозируемые по сейсмическим данным и предполагаемые.

Подробно охарактеризовано распространение куонамского горизонта, состоящего из кембрийских пород, обогащенных органическим веществом. Это кумахская и синскокуторгиновая толщи, иниканская и куонамская свиты. По времени формирования куонамский горизонт разделен на два этапа: первый - соответствует ботомскому веку, второй - тойонскому и началу майского веков. Куонамский горизонт перекрыт более молодыми отложениями майского яруса, имеющими косослоистое строение.

В результате исследований построены схемы фациального районирования кембрийских отложений на ботомское, тойонско-раннемайское и среднемайское время с детальностью, отвечающей современному уровню геолого-геофизической изученности Вилюйской гемисинеклизы.

Вилюйская гемисинеклиза, куонамская свита, иниканская свита, данные бурения, кембрий, временной разрез, сейсмофациальный анализ, рифогенные постройки. 


\section{ВВЕДЕНИЕ}

Вилюйская гемисинеклиза (рис. 1), площадь которой более 200 тыс. км², одна из немногих пока еще малоизученных территорий Сибирской платформы, которая может претендовать на открытие крупных и гигантских залежей газа, связанных с кембрием. К настоящему времени на ее территории открыто 11 газоконденсатных месторождений, большинство из них приурочено к двум крупным положительным структурам: Хапчагайскому мегавалу и Логлорскому валу [Погодаев, Ситников, 2008; Погодаев, 2018; Погодаев и др., 2012, 2015]. Все они локализованы в стратиграфическом интервале от верхней перми до нижней юры.

Поиск месторождений углеводородов, детальное изучение геологического строения, истории образования глубокопогруженных нефтяных и газовых систем докембрия и раннего палеозоя, в том числе черносланцевых и рифовых комплексов кембрия, актуальны и выполняются в осадочных бассейнах северо- и юго-западных, а также центральных районов Китая [Cai et al., 2009; Gao, Fan, 2015; Gong et al., 2007; Huang Jinliang et al., 2012; Shi et al., 2018; Wei Guoqi et al., 2015], Южного Омана [Schoenherr et al., 2007] и др..

Оценка генерации сланцевого газа и потенциала пород аномально обогащенных высокозрелым органическим веществом проведена для формации Цюнчжуси нижнего кембрия, распространенной в Южном Сычуаньском бассейне [Huang Jinliang et al., 2012]. Она показала, что на глубинах до 3 км черные сланцы содержат высокие содержания газа, формация является перспективной для промышленного производства сланцевого газа. Изучен сухой газ центральной части Сычуальского бассейна с глубин 4500-6000 м [Wei Guoqi et al., 2015]. Исследование компонентного состава газов и изотопного состава углеводородных газов позволили установить, что природный газ докембрийских и кембрийских отложений, с одной стороны, является продуктом крекинга нефтей, с другой, - связан с реализацией кембрийских нефтематеринских пород. Гигантское скопление природного газа недавно обнаружено в резервуарах неопротерозойской формации Дэнджин в Сычуаньской впадине юго-западного Китая [Shi et al., 2018]. Оно является новым дополнительным примером известных неопротерозойско-кембрийских нефтегазоносных систем древних платформ Земли. Геолого-геохимическое исследование структуры осадочных комплексов, генерации и миграции углеводородов дало возможность китайским ученым обсуждать пять возможных нефтегазопроизводивших формаций неопротерозоя и кембрия. Основным генератором газов считают глинистые сланцы нижнего кембрия, распространенные в центральном бассейне Сычуань [Shi et al., 2018]. 
Положительный опыт получен при исследовании и сопоставлении биомаркеров нефтей и нефтематеринских комплексов кембрия и ордовика с глубин более 5 км, Таримского бассейна на северо-западе Китая [Cai et al., 2009; Gong et al., 2007]. Известно, что породы кембрия и ордовика в этом бассейне погружаются до 6-10 км. Изучение авторами геохимии нефтей Луннаньского поднятия, моделирование истории погружения и изменения температуры осадочных комплексов показали, что зрелые нефти из ордовикских резервуаров с глубин от 5038 до 5801.4 м генерированы кембрийскими и ордовикскими нефтематеринскими породами [Gong et al., 2007].

Петрографические и геохимические исследования твердых битумов, распространенных в коллекторах группы Ара от позднего докембрия до раннего кембрия на глубине 3-5 км, позволили выявить многофазную термическую эволюцию глубокопогруженной нефтяной системы в Южно-Оманском соленосном бассейне. Пиролиз, битуминология, газо-жидкостная хроматография компонентов органического вещества показали, что твердый битум в карбонатных коллекторах Ара происходит из карбонатных, эвапоритовых нефтематеринских пород [Schoenherr et al., 2007].

По инициативе В.Е. Савицкого с 1974 г. в рамках единой программы началось планомерное комплексное исследование кембрийских рифовых образований и в целом фациальной зональности кембрия на Сибирской платформе [Конторович, Савицкий, 1970, Савицкий, Асташкин, 1979]. Однако в начале 1990-ых гг. программа была свернута, бурение и сейсмические работы прекращены. Региональные сейсмические работы на Вилюйской гемисинеклизе были возобновлены лишь с 2013 г и сосредоточены в основном в пределах ее южного борта. Кембрийские отложения остаются слабо изученными, а их нефтегазоносный потенциал не раскрыт до сих пор.

В кембрийском периоде практически всю территорию Сибирской платформы занимал морской бассейн. С запада на восток выделялись три зоны с различными морскими режимами осадконакопления. В изолированной от океана обширной западной части бассейна (Турухано-Иркутско-Олекминский фациальный регион) имела место повышенная соленость вод и шло эвапоритовое накопление мелководных осадков лагунного типа (соли, гипс, ангидрит, прослои известняков). Этот участок палеобассейна Анабаро-Синский фациальный регион) был ограничен полосой развития органогенных построек (Сахайская органогенная полоса). В современных разрезах отложения этой зоны представлены органогенными известняками. На востоке платформы располагалась зона открытого шельфа (Юдомо-Оленекский фациальный регион), более глубокий участок палеобассейна, на котором в начале раннего кембрия накапливались глинистокарбонатные осадки, а начиная с ботомского века раннего кембрия и до конца амгинского 
века среднего кембрия осадки, обогащенные органическим веществом. В современном разрезе они представлены - синской, куторгиновой, куонамской и иниканской свитами.

В пределах Вилюйской гемисинеклизы и прилегающих территорий кембрийские отложения к настоящему времени вскрыты 35 глубокими и колонковыми скважинами. Кембрий выходит на дневную поверхность на юге исследуемой территории (на склоне Алданской антеклизы, обнажаясь в бассейнах рек Лена, Алдан, Амга и др.) и на северозападе (на склоне Анабарской антеклизы, в береговых обнажениях рек Тюнг, Линде, Серки и др.).

Аномально обогащенные органическим веществом породы куонамского горизонта можно рассматривать не только как потенциально нефтепроизводившие, но и как нефтегазоносные [Геология нефти и газа, 1981, Каширцев, Конторович, 2006; Парфенова; 2005; Парфенова и др., 2014, 2016; Ситников и др., 2013; Старосельцев, 2013]. На перспективы нефтегазоносности кембрийских отложений Вилюйской гемисинеклизы указывают данные бурения. В частности, в свитах майского яруса среднего кембрия, перекрывающих куонамский горизонт, были отмечены повышенная пористость (до 1618\%), трещиноватость (происходили обвалы стенок скважины), выпоты нефти, интенсивная битуминозность. В скважине Тюкян-Тюнгская-1 получены притоки газа из ордовикских отложений, источником которого могли служить отложения кембрия. Признаки газоносности нижне-среднекембрийских отложений получены в процессе испытания Усть-Мархинской параметрической и Уордахской поисковой скважин. В скв. Среденконончанская-1 при испытании интервала 3359,4-3411,5 м (удачнинская свита) получена сильногазированная жидкость дебитом 828 м³/сут. В скв. Синская-1 из керна кумахской толщи (аналог синско-куторгиновой толщи) сочились капли жидкого битума. За пределами гемисинеклизы известна Бологурская нефтяная залежь в танхайской свите среднего кембрия, вскрытая гидрогеологическими скважинами в бассейне р. Амги [Геология нефти и газа, 1981, Каширцев, 2003]. Битумопроявления в породах куонамского горизонта и перекрывающих отложений встречены в опорных разрезах на обнажениях и в керне скважин на восточном склоне Анабарской антеклизы и на северном склоне Алданской антеклизы [Геология нефти и газа..., 1981; Каширцев, Конторович, 2006; Парфенова; 2005; Парфенова и др., 2014, 2016]. На основании палеотектонических построений, материалах о нефтегазопроизводящем потенциале куонамской свиты и ее возрастных и фациальных аналогах, анализа геолого-геохимических предпосылок нефтегазоносности российскими исследователями обосновано выделение нового нефтеносного района на южном борту Вилюйской синеклизы [Ситников и др., 2013]. В качестве объекта для поисков залежей нефти рассматривают базальные песчаные слои 
пермских отложений, карбонатные горизонты рифового и доманикового типа кембрия вблизи Западно-Якутской рифовой системы.

Цель настоящей работы - исследование строения, построение модели стратиграфического и латерального распространения глубокопогруженных кембрийских отложений на территории Вилюйской гемисинеклизы на основании комплексного анализа материалов бурения и интерпретации сейсмических данных.

\section{СОВРЕМЕННЫЕ ПРЕДСТАВЛЕНИЯ О СТРАТИГРАФИИ И СТРОЕНИИ КЕМБРИЙСКИХ ОТЛОЖЕНИЙ}

Фактический материал, положенный в основу работы, методика его анализа и переинтерпретации, а также основные аспекты сейсмогеологического строения осадочного чехла Вилюйской гемисинеклизы и прилегающих территорий рассмотрены в работе [Губин, 2020]. В данном исследовании главный акцент сделан на кембрийские отложения, их стратиграфический и сейсмофациальный анализ.

В Сюгджерской седловине кембрийские отложения вскрыты и изучены в скважинах Мархинско-Андойская-323-1 и Чучуканская-1 (рис. 2).

В скв. Мархинско-Андойская-323-1 разрез нижнего кембрия представлен билирской свитой, толщей пестроцветных известняков и нижней частью куонамской свиты, нижний средний кембрий. В среднекембрийском интервале разреза, выше куонамской свиты выделены оленекская, джахтарская, силигирская. Верхний кембрий представлен джуктинской свитой.

Скважина Чучуканская-1 вскрыла кембрийские эвапоритовые отложения, характерные для Турухано-Иркутско-Олекминского фациального региона Сибирской платформы. Нижнекембрийские отложения на этой территории включают билирскую, пестроцветную, удачнинскую, чарскую свиты и нижнюю часть ичерской свиты (рис. 2). Отложения представлены доломитами, известняками, ангидритами. Мощность нижнекембрийской части разреза более 1239 м [Стратиграфия нефтегазоносных..., 2016]. В среднекембрийской части разреза выделены ичерская (верхняя часть), метегерская, хабардинская, малыкайская и мархинская (самые низы) свиты [Стратиграфия нефтегазоносных..., 2016]. Породы амгинского яруса (верхняя часть ичерской и метегерская свиты) представлены серыми и светло-серыми доломитами с прослоями мергелей и аргиллитов. Майский ярус среднего кембрия сложен мергелями красноцветными доломитовыми, известково-доломитовыми, пестроцветными глинистыми, алевритоглинистыми доломитами, аргиллитами, гипсами, формировавшимися в условиях внутреннего шельфа. Мощность среднекембрийской части 
разреза около 800 м. Отложения верхнего кембрия (мархинская свита и низы олдондинской свиты) сложены переслаивающимися известняками, доломитами глинистыми, обломочно-оолитовыми, водорослевыми, мергелями, аргиллитами, силикатно-карбонатными алевролитами. Мощность - 1366 м [Стратиграфия нефтегазоносных..., 2016].

Кембрийские отложения согласно залегают на вендских толщах и согласно перекрываются отложениями нижнего ордовика.

В Ыгыаттинской впадине кембрийские отложения развиты повсеместно. Интерпретация сейсмических данных показывает, что кембрийские комплексы, вскрытые скважинами Конончанская-2450, Далырская-2560, Усть-Мархинская-1, Меикская-2231, Сыгдахская-410 (рис. 1, 3), прослеживаются непрерывно с погружением к центральным районам Вилюйской гемисинеклизы (рис. 4). Полный разрез кембрия вскрыт скважиной Меикская-2231. Нижний кембрий согласно залегает на породах венда. Он представлен в интервале 2955-3912 м верхней частью юряхской, билирской, сыгдахской, эльгянской, толбачанской и олекминской свитами (см. рис. 3). В среднем кембрии выделяются чарская, ичерская, метегерская свиты в интервале 2130-2955 м. Верхний кембрий представлен бордонской, джуктинской и чаргольской свитами в интервале 1281-2130 м. Чарголькая свита перекрывается согласно, местами с небольшим перерывом балыктахской свитой, которая датируется возрастам поздний кембрий - ранний ордовик.

На северо-западном борту Вилюйской гемисинеклизы (Хоргочумская моноклиналь) кембрий вскрыт Среднеконончанской-1 и Северо-Линденской-1 скважинами (рис. 1, 2). Результаты переинтерпретации сейсмических материалов, полученных Хоргочумской № 15/82-83 и Линденской № 16/82-83 сейсморазведочными партиями, показывают, что кембрийские отложения развиты повсеместно в пределах Хоргочумской моноклинали (рис. 5). Комплекс кембрийских отложений с флексурообразным перегибом погружается в направлении к Логлорскому валу и Линденской впадине, в пределах которой его подошва прогнозируется на глубинах до 10 км. Он согласно залегает на вендском комплексе. Самые древние породы, вскрытые скважиной Среднеконончанская-1 - это породы второй половины нижнего кембрия [Стратиграфия нефтегазоносных..., 2016]. Нижнекембрийская часть разреза представлена синско-куторгиновой толщей, вскрытой на глубине 3610-3700 м. Толща сложена темно-серыми, черными известняками (мощность 90 м). Эти отложения характерны для Юдомо-Оленекского фациального региона (область открытого шельфа). Верхняя часть нижнего кембрия представлена нижней частью удачнинской свиты (полный объем свиты со среднекембрийской частью в интервале 3010-3610 м). Свита сложена водорослевыми и органогенно-обломочными известняками с прослоями песчаников. Эти 
отложения накапливались в области развития органогенных построек (Сахайская органогенная полоса, Анабаро-Синский фациальный регион). Среднекембрийский разрез включает верхнюю часть удачнинской свиты, зеленоцветную, чукукскую, хабардинскую и малыкайскую свиты. Верхнекембрийская часть разреза состоит из мархинской и нижней части олдондинской свит, сложенных мергелями, доломитами, прослоями песчаников и алевролитов. Кембрийские отложения согласно перекрываются породами нижнего ордовика.

Скважиной Северо-Линденская-1 разрез нижнего и среднего кембрия вскрыт в интервале 2548-3170 м. Породы нижнего кембрия в скважине представлены пестроцветными известняками, темно-серыми карбонатными породами. Кембрийские отложения согласно залегают на породах венда и с перерывом перекрываются пермскими отложениями. Мощность кембрийских отложений около 700 м.

На западе Вилюйской гемисинеклизы, между Ыгыаттинской и Линденской впадинами, а также Кемпендяйской и Тангнарынской впадинами расположена ТюкянЧыбыдинская моноклиналь. Результаты интерпретации сейсмических данных, полученных Ханнинской сейсморазведочной партией № 2/79-80 и № 14/80-81, а также современных региональных сейсмических работ, выполненных за счет федерального бюджета на Западно-Вилюйской площади, [Кольга, 2019] показывают, что кембрийские отложения развиты повсеместно в пределах Тюкян-Чыбыдинской моноклинали, погружаясь в юго-восточном направлении (рис. 6). В пределах моноклинали кембрийские отложения вскрываются скважинами Южно-Сагытайскими-290, 291, 292, Уданской-295, Нижнетюкянской-311. Наиболее полный кембрийский разрез вскрыт скважиной Уданская295. Самые древние породы в скважине - синско-куторгиновая толща и нижняя часть удачнинской свиты второй половины нижнего кембрия [Стратиграфия нефтегазоносных..., 2016]. Среднекембрийская часть представлена карбонатнотерригенными породами верхней части удачнинской свиты, карбонатно-глинистой толщей, зеленоцветной, чукукской, хабардинской и малыкайской свитами. В верхнекембрийской части разреза установлены мархинская и олдондинская свиты. Другие скважины (ЮжноСагытайские и Нижнетюканская-311) вскрыли только часть верхнего кембрия. В скважине Нижнетюканская-311 - это части джуктинской и бордонской свит, в Южно-Сагытайских скважинах - часть чаргольской свиты (рис. 3).

Кембрийские отложения в пределах моноклинали согласно залегают на породах венда. На части этой территории они также согласно перекрываются ордовикскими толщами. В скважине Нижнетюкянская-311 кембрийские отложения с перерывом перекрываются девонскими толщами. 
На обширной территории южного борта Вилюйской гемисинеклизы кембрийские отложения вскрыты многими скважинами, расположенными на склоне Алданской антеклизы (Баппагайская-1, Северо-Синская-2160, Синская-1, Уордахская-1) и структур, примыкающих к ней на юго-западе: Наманинский выступ, Сарсанский прогиб, АрбайскоСинский мегавал) (рис. 1).

В пределах Арбайско-Синского мегавала нижний кембрий вскрыт скважинами Арбайская-2, Восточная-491, Верхнесинская-3, Кумахская-2. Он представлен билирской, сыгдахской, эльгянской, толбачанской, олекминской, чарской и низами ичерской свит (рис. 7). Эти свиты характерны для Турухано-Иркутско-Олекминского фациального региона нижнего кембрия Сибирской платформы. В скважине Верхне-Синская-3 верхней части атдабанского яруса соответствует толща массивных доломитов. Вышележащая олекминская свита соответствует ботомскому ярусу. Большая часть толщи нерасчлененных ичерской и чарской свит соответствуют тойонскому ярусу.

Аналогичный разрез нижнего кембрия вскрыт скважинами Верхнесинская-1 в Сарсанском прогибе, скв. Северо-Наманская-1, расположенной на Наманинском выступе (рис. 1, 7). Мощность нижнего кембрия здесь составляет около 800 м.

Разрез нижнего кембрия характерный для Анабаро-Синского фациального региона (Сахайская органогенная полоса) вскрывается на борту Алданской антеклизы скважинами Северо-Синская-2160 и Синская-1 (рис. 1, 7). Он представлен синской свитой и перекрывающей ее толщей водорослево-зернистых и глинистых известняков [Стратиграфия нефтегазоносных..., 2016]. В этих скважинах мощность нижнего кембрия более 1100 м.

Разрез нижнего кембрия, вскрытый скважинами Баппагайская-1 и Уордахская-1 является типичным для Юдомо-Оленекского фациального региона Сибирской платформы (зона открытого шельфа). Здесь на пестроцветной свите залегает иниканская свита, нижняя часть которой соответствует второй половине нижнего кембрия. Мощность нижнего кембрия в этих скважинах около 300 м.

Средний кембрий на территории Наманинского выступа, Сарсанского прогиба и Арбайско-Синского мегавала представлен верхней частью ичерской, метегерской и бордонской свитами, а в скважине Верхне-Синская-3 верхней частью нерасчлененных ичерской и чарской свит. Выше залегает метегерская свита (инт. 2290-2378 м). Майскому ярусу соответствует бордонская свита (инт. 2116-2290 м). Суммарная мощность среднего кембрия составляет более 300 м.

В скважинах Синская-1, Северо-Синская-2160 амгинский ярус сложен толщей водорослево-зернистых известняков. В скважине Синская-1, вышележащих кембрийских 
отложений нет, а в скважине Северо-Синская-2160 толща водорослево-зернистых известняков перекрывается нижней частью бордонской свиты. В скважине Баппагайская-1 амгинский ярус представлен верхней частью иниканской свиты. Выше залегают устьботомская свита (инт. 1870-2260 м), баппагайская свита (инт. 1548-1870 м), бордонская свита (инт. 1342-1548 м). Мощность среднего кембрия в скважине более 500 м.

Верхнекембрийские отложения вскрыты скважинами Баппагайская-1 и ВерхнеСинская-3. В скважине Баппагайская-1 в интервале 1060-1342 м установлена джуктинская свита (соответствует аюсокканскому и сакскому ярусам). В скважине Верхне-Синская-3 выделяется толща нерасчлененных чаргольской и джуктинской свит (соответствует аюсокканскому, сакскому, аксайскому ярусам). Мощность верхнекембрийских отложений более 500 м.

Верхнекембрийские отложения на территории Наманинского выступа, Сарсанского прогиба и Арбайско-Синского мегавала перекрываются породами среднего девона. На северном склоне Алданской антеклизы кембрийские отложения перекрываются нижней юрой.

В пределах Кемпендяйской впадины под верхнедевонскими толщами скважины Атыяхская-451 и Эселяхская-3010 (рис. 1) в призабойной зоне в интервалах 3468-3582 м и 4000-4071 м соответственно вскрыли серые пелитоморфные ангидритизированные доломиты. Фауны в них обнаружено не было. Первоначально они были отнесены к нижнему палеозою, позже Граусман В.В. отнесла их к меикской свите нижнего силура [Граусман, 1994]. Однако аналогичные ангидритизированные серые глинистые известняки и доломиты, датируемые поздним кембрием, вскрыты под верхним девоном ближайшими скважинами на Арбайской, Восточной, Верхнесинской площадях. Силурийских отложений, доказанных палеонтологическими данными, в Кемпендяйской впадине нет, поэтому в настоящей работе возраст отложений, вскрытых на забое скважинами Атыяхская-451 и Эселяхская-3010, был принят как позднекембрийский. Согласно сейсмическим данным, кембрийский комплекс развит в пределах всей территории Кемпендяйской впадины, он согласно залегает на вендском комплексе и перекрывается отложениями девона (Рис. 8).

На обширных территориях внутренней части Вилюйской гемисинеклизы кембрийские отложения не вскрыты скважинами. Однако, анализ современных сейсмических материалов, полученных в последние годы за счет средств федерального бюджета на Южно-Вилюйской, Западно-Вилюйской, Синской и Якутской площадях показывает, что кембрий, вскрытый скважинами в прибортовых районах Вилюйской 
гемисинеклизы, уверенно прослеживается на временных разрезах к ее центральным районам, погружаясь до глубин 10-14 км.

Таким образом, можно констатировать, что кембрийские отложения повсеместно развиты в Вилюйской гемисинеклизе и прилегающих территориях, за исключением большей части Сунтарского свода, а также Якутского свода и Китчанского выступа.

\section{РАСПРОСТРАНЕНИЕ КУОНАМСКОГО ГОРИЗОНТА}

Поскольку аномально обогащенные органическим веществом породы куонамского горизонта можно рассматривать как потенциально нефтепроизводившие и как нефтегазоносные, в работе проанализировано не только их стратиграфическое, но и латеральное распространение.

K куонамскому горизонту на территории Вилюйской гемисинеклизы относятся кумахская и синско-куторгиновая толщи, иниканская (распространена на юго-востоке Сибирской платформы) и куонамская свиты. Горизонт имеет стратиграфическое распространение от низов ботомского яруса нижнего кембрия до низов майского яруса среднего кембрия. Он перекрыт более молодыми отложениями майского яруса, характеризующимися косослоистым строением.

Куонамский горизонт вскрывается несколькими скважинами в пределах изучаемой территории и ее непосредственного обрамления. Естественные обнажения куонамского горизонта имеются южнее (реки Лена, Мая, Юдома, Иникан и др.) [Конторович, Савицкий, 1970, Савицкий и др., 1972; Розанов и др., 1992 и др.] и севернее Вилюйской синеклизы (реки Кюленке, Муна, Молодо и др.) [Бахтуров и др., 1988; Шабанов и др., 2008 и др.]. Кроме этого имеются геологические и геофизические данные (в первую очередь, данные бурения и сейсморазведки), которые с разной степенью уверенности позволяют предполагать распространение горизонта на разных участках изучаемой территории [Геология нефти и газа, 1971, Конторович и др., 1981, Асташкин и др., 1985; Умперович и др., 1989; Старосельцев, Шишкин, 2014; Сивцев и др., 2017; Губин, Поспеева, 2017 и др.].

По времени формирования куонамский горизонт можно разделить на два этапа: первый - соответствует ботомскому веку, второй - тойонскому и началу майского веков. Перекрывающая толща заполнения сформирована в основном в майском веке.

Ботомский ярус. В ботомском веке раннего кембрия формировались кумахская, синско-куторгиновая толщи и нижние части иниканской и куонамской свит.

В пределах Арбайско-Синского мегавала скважинами на Кумахской площади вскрыта кумахская толща, представленная темно-серыми, черными, глинистыми известняками. Аналогичные отложения вскрываются скважинами Северо-Синская-2160 и 
Синская-1, расположенными на северо-западном склоне Алданской антеклизы (рис. 1, 7). Здесь они выделены в синско-куторгиновую толщу [Стратиграфия нефтегазоносных..., 2016]. Эти же породы в данных скважинах В.В. Граусман относила к кумахской толще [Граусман, 1994]. Вероятно, здесь речь идет об одной и той же толще. Породы, вскрытые вышеуказанными скважинами, имеют сходный литологический состав и близкие значения мощностей (скв. Кумахская-2 - 430 м; скв. Синская-1 и Северо-Синская-2160 - 390 м).

Также синско-куторгиновая толща выделяется в скважинах Среднеконончанская-1 и Уданская-295, расположенных в пределах Хоргочумской моноклинали, около границы Ыгыаттинской впадины (рис. 2). В этих скважинах толща вскрыта не полностью. В скв. Среднеконончанская-1 вскрыто 90 м, а в скв. Уданская-295 - 252 м.

Синско-куторгиновая и кумахская толщи накапливались вблизи области распространения фаций барьерно-рифового комплекса со стороны открытого бассейна. В скважинах Кумахской, Северо-Синской и Синской площадей отложения фаций барьернорифового комплекса ботомского возраста не вскрыты. Однако по современным сейсмическим данным, полученным на Синской площади, сейсмофации, интерпретируемые как органогенные постройки Западно-Якутской барьерно-рифовой системы, прослеживаются в виде широкой (около 40 км) полосы юго-восточного простирания. За пределами этой полосы на восток и северо-восток в сторону фаций открытого бассейна по сейсмическим данным установлено распространение иниканской свиты, вскрытой скважинами на Кенкеминской, Уордахской площадях и серией гидрогеологических скважин вблизи р. Лена (рис. 9). Не исключено, что зона распространения сейсмофаций барьерно-рифового комплекса может включать в себя и синско-куторгиновую толщу ботомского возраста, не формирующую в отличие от иниканской свиты устойчивой отраженной волны.

Около скважин Среднеконончанская-1 и Уданская-295 отложения барьерно-рифового комплекса вскрыты скважиной Чучуканская-1 (рис. 2). Они представлены удачнинской свитой, сложенной доломитами и органогенными известняками [Стратиграфия нефтегазоносных..., 2016]. Сейсмофации рифогенного комплекса отложений фиксируются на единичных разрезах по профилям около скважин Уданская-295, Усть-Мархинская-1 и Чучуканская-1.

Согласно современным сейсмическим данным, проведенным в пределах югозападной части Вилюйской синеклизы, комплексы кембрийских отложений прослеживаются на северо-восточном склоне Сунтарского свода. Здесь они разбиты разломами, образующими структуры типа надвигов, и погружаются в сторону центральных районов Вилюйской синеклизы (рис. 6). Среди них прослеживается 
отражающий горизонт, предположительно связанный с куонамской свитой. Юго-западнее кембрийские отложения полностью срезаются на Сунтарском своде средневерхнепалеозойскими перерывом.

Таким образом, распространение синско-куторгиновой толщи и ее аналога кумахской толщи предполагается вдоль области фаций барьерно-рифового комплекса, которая в ботомском веке раннего кембрия протягивалась полосой с юго-востока на северо-запад от северного склона Алданской антеклизы к Сюгджерской седловине и отделяла область фаций открытого бассейна от области солеродного бассейна (рис. 9). Отложения солеродного бассейна вскрыты скважинами Северо-Наманинская-1, Кугосанская-2191, Верхнесинская-1, 3, Восточная-491 и Арбайская-2 в пределах Арбайско-Синского мегавала и Сарсанского прогиба. Ботомский ярус представлен в разрезах этих скважин олекминской свитой, которая состоит из доломитов, ангидритов, глинистых известняков. Кембрийские толщи, в том числе ботомского яруса, стратифицированные по скв. Арбайская-2, прослеживаются на отдельных временных разрезах в пределах Кемпендяйской впадины под мощной толщей среднепалеозойско-мезозойских отложений вплоть до Сунтарского свода (рис. 8). На самом своде эти отложения отсутствуют. Аналогичные отложения присутствуют в разрезе скважин Сыгдахская-410, Меикская-2231, Далырская-2560 и Усть-Мархинская-1, расположенных в пределах Ыгыаттинской впадины.

Нижняя часть (соответствующая ботомскому ярусу) иниканской свиты вскрывается несколькими скважинами: Баппагайская-1, Уордахская-1, Кенкеминская-3 и др. Свита сложена темно-серыми, черными тонкослоистыми известняками и мергелями с прослоями аргиллитов [Асташкин и др., 1985]. На временных разрезах Южно-Вилюйской, Синской и Якутской площадей отражающий горизонт, приуроченный к иниканской свите, уверенно коррелируется от северного склона Алданской антеклизы вплоть до южного склона Хапчагайского мегавала. Далее на север его корреляция затрудняется вследствие погружения отложений иниканской свиты на значительную глубину.

Нижняя часть куонамской свиты, сложенная темно-серыми, черными известняками и аргиллитами, соответствующая ботомскому ярусу, вскрыта на южном склоне Анабарской антеклизы скважиной Эикская-3430, в пределах Сюгджерской седловины скважиной Мархинско-Андойская-3231 и на северной части изучаемой территории скважиной Северо-Линденская-1.

Таким образом, данные, полученные в результате глубокого бурения, и сейсмические данные позволяют установить на изучаемой территории широкое, практически повсеместное, распространение ботомской части куонамского горизонта. Доказанная 
бурением и сейсмическими данными территория распространения горизонта представляет собой широкий пояс (светло-синяя сплошная краска на рис. 9), простирающийся от северного склона Алданской антеклизы, через Чыбыдинскую и Хоргочумскую моноклинали, Сюгджерскую седловину и южному склону Анабарской антеклизы. Предполагаемое распространение куонамского горизонта значительно шире (светло-синие полоски на рис. 9). Вероятнее всего она простирается на восток под мощными перекрывающими толщами вплоть до Предверхоянского краевого прогиба.

Тойонский - низы майского яруса. Границы распространения куонамского горизонта на уровне нижней части тойонского яруса и до низов майского яруса среднего кембрия несколько изменяются. Относительно узкая полоса, протягивающаяся вдоль области фаций барьерно-рифового типа, на которой в ботомском веке накапливались синско-куторгиновая и кумахская толщи, оказалась в зоне этой фации (рис. 10). Так на северном склоне Алданской антеклизы в скважинах Синская-1 и Северо-Синская-2160 вскрыта толща рифогенных водорослево-зернистых и глинистых известняков мощностью от 376 м (скв. Синская-1) до 808 м (скв. Северо-Синская-2160), которые перекрывают на этом участке синско-куторгиновую толщу.

На Баппагайском выступе по сейсмическим данным, полученным в 1980-ых годах силами Рифовой сейсмопартии № 18/83-84, по динамическому и кинематическому анализу волновых полей в районе Кусоганской, Верхнесинской, Кумахской, Синской и СевероСинской площадей выделялись аномалии типа «массивное тело», интерпретируемые как отдельные биогермы. Их глубины залегания изменяются от 1000 до 2400 м, мощности составляют 500-700 м.

В скважине Кумахская-2 куонамский горизонт ботомского возраста (кумахская толща) перекрывается толщами, характерными для фаций солеродного бассейна (чарская, ичерская свиты) (рис. 7). Предполагаемая область распространения фаций барьернорифового комплекса расположена северо-восточнее кумахских скважин.

Выявленные аномалии волнового поля в районе Кумахской площади, связываемые с отдельными рифовыми постройками, могут свидетельствовать о близком расположении переходной зоны от солеродного бассейна к фациям открытого бассейна. Также несколько изменяются границы распространения куонамского горизонта для интервала тойонского яруса - низов майского яруса на территории сочленения Сюгджерской седловины, Хоргочумской моноклинали и Ыгыаттинской впадины. В разрезе, вскрытом скважинами Среднеконончанская-1 и Уданская-295, выше синско-куторгиновой толщи выделяется удачнинская свита, сложенная органогенными известняками. Здесь также согласно предшествующим работам тематической партии № 40/32-33 [Дорман и др., 1984] выявлен 
ряд аномалий, связанных как с рифовыми зонами, так и с куонамской формацией. Анализ полученных данных позволяет сделать вывод о том, что зона развития биогермов частично перекрывает поле установленного распространения фаций открытого бассейна.

Таким образом, на исследуемой территории фации барьерного типа сместились в тойонском - начале майского веков на восток, несколько сократив поле распространения отложений куонамского горизонта.

Установленное и предполагаемое распространение иниканской и куонамской свит для интервала тойонского - начало майского ярусов существенно не изменилось по сравнению с ботомским ярусом. Доказанная бурением и сейсмическими данными территория распространения их по-прежнему представляет собой широкий пояс, простирающийся от северного склона Алданской антеклизы, через Чыбыдинскую и Хоргочумскую моноклинали, Сюгджерскую седловину к южному склону Анабарской антеклизы. Предполагаемое распространение куонамского горизонта также простирается на восток вплоть до Предверхоянского краевого прогиба (рис. 10).

Майский ярус. В майском веке во второй половине времени Tomagnostus fissus Acadoparadoxides sacheri на всей изучаемой территории произошло существенное изменения в характере осадконакопления. Полностью исчезают области распространения фаций солеродного и открытого бассейнов. Соответственно, прекращается накопление куонамского горизонта. Область распространения фаций барьерно-рифового комплекса значительно сокращается (рис. 11). Скважины Баппагайская-1 и Андреевская-2 вскрыли светло-серые, белые, органогенные известняки (баппагайская свита) имеющие среднемайский возраст (зона Anomocarioides limbataeformis). В районе расположения этих скважин по сейсмическим данным в майском интервале разреза устанавливаются аномалии волнового поля типа «риф». Также в скважинах Среднеконончанская-1 и Уданская-295 выделена чукукская свита аналогичного возраста. Она сложена органогенными известняками, обломками известняков, содержит примесь терригенного материала. Она представляет собой карбонатный баровый комплекс, оконтуривающий Далдыно-Мархинскую банку [Сухов, 2001].

Вся остальная территория Вилюйской синеклизы и прилегающие территории характеризуются распространением пород, представляющих собой обломочные карбонатные, терригенные толщи, часто с прослоями доломитов, мергелей. На северном склоне Алданской антеклизы на современных сейсмических разрезах Синской и ЮжноВилюйской площадей фиксируется косослоистый (клиноформный) рисунок сейсмозаписи, отвечающий комплексу майских отложений. Подобный характер строения внутрикембрийских отложений наблюдается севернее скв. Северо-Синская-2160 на 
временных разрезах Рифовой площади [Короткий и др., 1986] и интерпретируется как результат формирования, начиная со второй половины майского века, авандельтовой толщи заполнения в южной части глубоководного палеобассейна. Вероятным источником сноса терригенно-карбонатного материала были сооружения самой барьерно-рифовой системы, а также выступы фундамента, располагавшиеся на северном склоне Алданской антеклизы и Сунтарском своде, где в настоящее время отложения среднего и верхнего кембрия отсутствуют (серые и заштрихованные зоны на рис. 11).

\section{ЗАКЛЮЧЕНИЕ}

Выявление особенностей стратиграфического строения слабоизученных территорий на основе сейсмических данных начало успешно осуществляться еще с 60-70-ых годов прошлого века [Sheriff, 1976; Schneider, 1971; Сейсмическая стратиграфия, 1982 и др.]. Однако для всей территории Вилюйской гемисинеклизы применение такого подхода стало возможно лишь в последнее время с получением современной сейсмической информации.

На основании комплексного анализа результатов бурения и сейсмических данных показано распространение кембрийских отложений в пределах отдельных структур Вилюйской гемисинеклизы и прилегающих территорий (восток Сюгджерской седловины, Хоргочумская моноклиналь, север Ыгыаттинской впадины и Наманинского выступа, Тюкян-Чыбыдинская моноклиналь, Арбайско-Синский мегавал, Сарсанский прогиб, север Алданской антеклизы и др.). Кембрийские отложения отсутствуют на большей части Сунтарского свода и Китчанского выступа, а также на Якутском своде Алданской антеклизы. Дополнительно указаны взаимоотношения кембрийских толщ с подстилающими и перекрывающими отложениями.

Наиболее детально показано распространение куонамского горизонта (кембрийские породы аномально обогащенные органическим веществом: кумахская и синскокуторгиновая толщи, иниканская и куонамская свиты). Выявлено, что по времени формирования куонамский горизонт можно разделить на два этапа: первый соответствует ботомскому веку, второй - тойонскому и началу майского веков. Он перекрыт более молодыми отложениями майского яруса, характеризующимися косослоистым строением.

Куонамский горизонт является главной нефтегазопроизводящей толщей в нижнем среднем палеозое Сибирской платформы. Настоящее исследование отложений Вилюйской гемисинеклизы и анализ опыта изучения зарубежными коллегами раннепалеозойских глубокопогруженных осадочных комплексов Китая и Омана [Cai et al., 2009; Gao, Fan, 2015; Gong et al., 2007; Huang Jinliang et al., 2012; Schoenherr et al., 2007; Shi et al., 2018; 
Wei Guoqi et al., 2015] позволяют сделать следующие выводы. С генерацией углеводородов в черносланцевых кембрийских отложениях должны быть связаны зоны нефтенакопления на склонах Анабарской и Алданской синеклиз, в рифовом комплексе кембрия. Крупные скопления газа могли сохраниться в кембрийских отложениях куонамского горизонта и в выше залегающих отложениях кембрия.

Работа выполнена в рамках фундаментальных научных исследований № 0331-2019-0018 «Построение моделей геологического строения и оценка перспектив нефтегазоносности фанерозойских и неопротерозойских осадочных комплексов Лено-Тунгусской НГП для формирования программы геологоразведочных работ и лищензирования недр» и № 0331-2019-0003 «Палеонтологическое и экостратиграфическое обоснование зональных стратиграфических схем палеозоя Сибири, палеогеографическое и биофациальное районирование осадочных бассейнов».

\section{ЛИТЕРАТУРА}

Асташкин В.А., Шишкин Б.Б., Шабанов Ю.Я. и др. Стратиграфия кембрия Вилюйской синеклизы // Стратиграфия и палеонтология докембрия и фанерозоя Сибири. Новосибирск: СНИИГГиМС, 1985. - С. 22-31.

Бахтуров С.Ф., Евтушенко В.М., Переладов В.С. Куонамская битуминозная карбонатно-сланцевая формация. Труды ИГиГ, вып. 671, Новосибирск: Наука, 1988, 160 с.

Геология нефти и газа Сибирской платформы. / Ред. А.Э. Конторович, В.С. Сурков, А.А. Трофимук. М: Недра, 1981, 552 с.

Граусман В.В. Стратиграфия верхнего докембрия и фанерозоя перспективных на нефть и газ территорий Западной Якутии. Дисс. на соиск. канд. геол.-мин. наук в форме научного доклада. - Новосибирск, 1994. - 41 с.

Губин И.А. Уточнение строения Вилюйской гемисинеклизы по результатам переинтерпретации сейсморазведочных работ // Геология и минерально-сырьевые ресурсы Сибири. - № 4 (41), 2020. - С. 40-52.

Губин И.А., Поспеева Н.В. Сейсмогеологическая модель и структурная характеристика юго-восточных районов Сибирской платформы по результатам комплексной интерпретации региональных и поисковых сейсморазведочных работ. // Технологии сейсморазведки, 2017, №2, с. 93-107. 
Дорман М.И., Янис А.И., Дорман Б.Л., Голярчук Н.А. Обобщение сейсморазведочного материала МОГТ, ВСП и МОВ, характеризующего Хоргочумскую моноклиналь, Логлорскую антиклинальную зону и прилегающие территории с целью построения карт изменения скорости, структурных карт по отражающим горизонтам и геолого-геофизических разрезов за 1982-1983 гг. - Якутск, 1984.

Каширцев В.А. Органическая геохимия нафтидов востока Сибирской платформы. Якутск: ЯФ Изд-ва СО РАН, 2003. - 160 с.

Каширцев В.А., Конторович А.Э. Алкилстераны и алкилтриароматические стероиды - новые биометки в докембрийских и кембрийских нефтях Непско-Ботуобинской и Алданской антеклиз (Сибирская платформа) // Геология и геофизика, 2006, т. 47, № 6, с. 812-819.

Кольга Л.А. Комплексные геофизические работы с целью изучения оценки перспектив нефтегазоносности, локализации прогнозных ресурсов УВ нефтегазоносных объектов юго-западной части Вилюйской синеклизы республики Саха (Якутия). - Москва, 2019.

Конторович А.Э., Евтушенко В.М., Ивлев Н.Ф., Ларичев А.И. Закономерности накопления органического вещества на территории Сибирской платформы в докембрии и кембрии. // Литология и геохимия нефтегазоносных толщ Сибирской платформы. М: Наука, 1981, с. 19-42.

Конторович А.Э., Савицкий В.Е. К палеогеографии Сибирской платформы в раннюю и среднюю кембрийские эпохи. // Вопросы литологии и палеогеографии Сибири: Тр. СНИИГГиМС, Вып. 106, Новосибирск, 1970, с. 95-108.

Короткий А.Г., Новоселова Г.И., Лекторский М.Ю. Отчет о результатах сейсморазведочных работ МОГТ на Рифовой площади за 1984-1985 гг. (Рифовая сейсморазведочная партия № 18/84-85). - Якутск, 1986.

Парфенова Т.М. Нафтидопроявление в породах малокуонамского горизонта среднего кембрия как доказательство первичной миграции нефти в куонамской свите (северовосток Сибирской платформы) // Геология, геофизика и разработка нефтяных и газовых месторождений, 2005, №7, с. 26-30.

Парфенова Т.М., Каширцев В.А., Коровников И.В. Новые находки нафтидопроявлений в породах среднего кембрия на северо-востоке Сибирской платформы // Нефтегазовая геология. Теория и практика: электрон. науч. Журнал, 2014, т. 9, № 2, c. 1-22 - http://www.ngtp.ru/rub/1/25_2014.pdf

Парфенова Т.М., Меленевский В.Н., Коровников И.В. Геохимия органического вещества углеродистых пород сэктэнской свиты нижнего и среднего кембрия (Чекуровская 
антиклиналь, северо-восток Сибирской платформы) // Геология нефти и газа, 2016, № 6, с. 97-106.

Погодаев А.В., Ситников В.С. Особенности геологического строения и разработки нижнетриасовых залежей Средневилюйского газоконденсатного месторождения на востоке Сибирской платформы // Геология нефти и газа, 2008, № 4, с. 30-39.

Погодаев А.В., Ситников В.С., Лысов Б.А. Литологические и гидродинамические особенности газоносности верхнепермских и нижнетриасовых отложений Хапчагайского района Вилюйской нефтегазоносной области. // Геология нефти и газа, 2012, № 4, с. 2-12.

Погодаев А.В., Ситников В.С., Буйдылло И.В. Перспективы нефтегазоносности и приоритетные направления дальнейших поисковых работ в Вилюйской НГО (Сибирская платформа). // Геология нефти и газа, 2015, № 2, с. 6-16.

Погодаев А.В. Влияние режима АВПД на условия формирования и сохранения залежей газа в верхнепермских отложениях Хапчагайского мегавала // Нефтегазовая геология. Теория и практика, 2018, т. 13, №4. https://doi.org/10.17353/2070-5379/39_2018

Розанов А.Ю., Репина Л.Н., Аполлонов М.К., Шабанов Ю.Я., Журавлев А.Ю., Пегель Т.В., Федоров А.Б., Асташкин В.А., Журавлева И.Т., Егорова Л.И., Чугаева М.Н., Дубинина С.В., Ермак В.В., Есакова Н.В., Сундуков В.В., Сухов С.С., Жемчужников В.Г. Кембрий Сибири. Новосибирск: Наука, 1992. 134 с.

Савицкий В.Е., Асташкин В.А. Роль и масштабы рифообразования в кембрийской истории Сибирской платформы // Геология рифовых систем кембрия Западной Якутии. Сб. науч. трудов СНИИГГИМС, 1979 г. - Вып. 270. - С. 5-18.

Савицкий В.Е., Евтушенко В.М., Егорова Л.И., Конторович А.Э., Шабанов Ю.Я. Кембрий Сибирской платформы. М: Недра, 1972. 200 с.

Сейсмическая стратиграфия. Использование при разведке нефти и газа / Ч. Пейтон. В 2-х частях. М.: Мир, 1982, 375 с.

Сивцев А.И., Зуева И.Н., Чалая О.Н. Структурная карта по толщинам и глубинам залегания кровли Куонамской горючесланцевой формации // Материалы VII Всерос. науч.практ. конф., посвящ. 60-летию ИГАиБМ СО РАН. - Якутск, 2017. - С. 233-237.

Ситников В.С., Кушмар И.А., Прищепа О.М., Погодаев А.В. О возможности открытия на юге Вилюйской синеклизы нового нефтеносного района (Сибирская платформа) // Геология нефти и газа, 2013, №3, с. 2-12.

Старосельцев В.С., Ефимов А.С., Соболев П.Н. Углеводородное сырье битуминозных пород Сибирской платформы // Геология нефти и газа № 5, 2013. - С. 73-80.

Старосельцев В.С., Шишкин Б.Б. Обстановки накопления углеродистых пород кембрия Сибирской платформы // Геология и геофизика, 2014, т. 55, № 5-6, С. 787-796. 
Стратиграфия нефтегазоносных бассейнов Сибири. Кембрий Сибирской платформы / С.С. Сухов, Ю.А. Шабанов, Т.В. Пегель и др. - Новосибирск: ИНГГ СО РАН, 2016. - 497 c.

Сухов С. С. Фациально-стратиграфическая модель Далдыно-Мархинской банки иллюстрация закономерностей карбонатонакопления на Сибирской платформе // Литология и нефтегазоносность карбонатных отложений / Материалы Второго Всероссийского литологического совещания и Восьмого Всероссийского симпозиума по ископаемым кораллам и рифам. - Сыктывкар: Геопринт. 2001. - С. 237-239.

Умперович Н.В., Еханин А.Е., Асташкин В.А., Роменко В.И., Шишкин Б.Б. Сейсмогеологическая модель кембрийских рифовых комплексов Якутии и возможности их изучения методом сейсморазведки // Геология и геофизика, 1989. - № 5. - С. 85-93.

Шабанов Ю.Я., Коровников И.В., Переладов В.С., Пак К.Л., Фефелов А.Ф. Разрез куонамской свиты на р. Молодо - кандидат глобального стратотипа нижней границы среднего кембрия (восток Сибирской платформы) // Разрезы кембрия Сибирской платформы - кандидаты в стратотипы подразделений Международной стратиграфической шкалы (стратиграфия и палеонтология). Новосибирск, Изд-во СО РАН, 2008, с. $59-70$.

Cai Ch, Li K., Anlai M., Zhang Ch., Xu Zh., Worden R.H. Distinguishing Cambrian from Upper Ordovician source rocks: Evidence from sulfur isotopes and biomarkers in the Tarim Basin // Organic Geochemistry, 2009, v. 40, p. 755-768.

Gao Zh., Fan T. Carbonate platform-margin architecture and its influence on CambrianOrdovician reef-shoal development, Tarim Basin, NW China // Marine and Petroleum Geology, 2015, v. 68, p. 291-306.

Gong S., George S.C., Volk H., Liu K., Peng P. Petroleum charge history in the Lunnan Low Uplift, Tarim Basin, China - Evidence from oil-bearing fluid inclusions // Organic Geochemistry, 2007, v. 38, p. 341-1355.

Huang Jinliang, Caineng Z., Jianzhong L., Dazhong D., Sheiiao W., Shiqian W., Keming Ch. Shale gas generation and potential of the Lower Cambrian Qiongzhusi Formation in the Southern Sichuan Basin, China // Petroleum exploration and development, 2012, v. 39, № 1, p. 75-81.

Schneider W.A. Developments in Seismic Data Processing and Analysis (1968-1970) // Geophysics, 1971, v. 36, No. 6, p. 1043-1073. https://doi.org/10.1190/1.1440232

Schoenherr J, Littke R., Urai J.L., Kukla P.A., Rawahi Z Polyphase thermal evolution in the Infra-Cambrian Ara Group (South Oman Salt Basin) as deduced by maturity of solid reservoir bitumen // Organic Geochemistry, 2007, v. 38, p. 1293-1318. 
Sheriff R.E. Inferring Stratigraphy from Seismic Data // The American Association of Petroleum Geologists Bulletin. Vol. 60. - No. 4 (April 1976). P. 528-542.

Shi C., Cao J, Tan X., Luo B, Zeng W., Hong H., HuangX., Wang Y. Hydrocarbon generation capability of Sinian-Lower Cambrian shale, mudstone, and carbonate rocks in the Sichuan Basin, southwestern China: Implications for contributions to the giant Sinian Dengying natural gas accumulation // AAPG Bulletin, 2018, v. 102, № 5, p. 817-853.

WEI Guoqi, XIE Zengye, SONG Jiarong, YANG Wei, WANG Zhihong, LI Jian, WANG Dongliang, LI Zhisheng, XIE Wuren Features and origin of natural gas in the Sinian-Cambrian of central Sichuan paleo-uplift, Sichuan Basin, SW China // Petroleum exploration and development, 2015, v. 42, № 6, p. 768-777.

William A. Schneider Developments in Seismic Data Processing and Analysis (1968-1970) // Geophysics. Vol. 36. - No. 6. - P. 1043-1073. 
Рис. 1. Обзорная схема района исследований с элементами тектонического районирования [Геология нефти и газа..., 1981]. Условные обозначения: 1 - скважины, вскрывшие кембрийские отложения (сокращенные названия буровых площадей и номера некоторых параметрических и поисковых скважин: СЛ - Северо-Линденская, Чк Чучуканская, ЮС - Южно-Сагытайская, Ск - Среднеконончанская, УМ - УстьМархинская, Ар - Арбайская, Км - Кумахская, Вс - Верхнесинская, СН - СевероНаманинская, С - Синская, Бп - Баппагайская, У - Уордахская, 3231 - МархинскоАндойская, 2450 - Конончанская, 295 - Уданская, 2560 - Далырская, 2231 - Меикская, 410 - Сыгдахская, 311 - Нижнетюкянская, 3010 - Эселяхская, 451 - Атыяхская, 492 Восточная, 2191 - Кусоганская, 2160 - Северо-Синская); 2 - населенные пункты; 3 гидросеть; 4 - профиль, по которому построены литостратиграфические схемы палеозоя отдельных структур Вилюйской гемисинеклизы и прилегающих территорий; границы тектонических структур: 5 - надпорядковых, 6 - I порядка (цифрами в кружках обозначены: 1 - Ыгыаттинская впадина, 2 - Тангнарынская впадина, 3 - АрбайскоСинский мегавал, 4 - Сарсанский прогиб, 5 - Наманинский выступ, 6 - Якутский свод, 7 Китчанский выступ).

Рис. 2. Литостратиграфическая схема палеозоя Сюгджерской седловины и Хоргочумской моноклинали (горизонтальной штриховкой показано предполагаемое распространение отложений по сейсмическим данным)

Рис. 3. Литостратиграфическая схема палеозоя Ыгыаттинской впадины и ТюкянЧыбыдинской моноклинали.

Рис. 4. Глубинный сейсмогеологический разрез по региональному композитному профилю № M02.

Рис. 5. Глубинные сейсмогеологические разрезы Хоргочумской моноклинали по линиям композитных профилей «А-А» (А) и «В-В» (Б) [по Дорман М.И., Жуковец Л.А., 1984 с дополнениями и изменениями].

Рис. 6. Фрагмент временного разреза по сейсмическому профилю ЗападноВилюйской площади № 160802 (интерпретация АО «ЦГЭ», 2019 г. с добавлениями) 
Рис. 7. Литостратиграфическая схема палеозоя северного склона Алданской антеклизы и прилегающих территорий.

Рис. 8. Глубинный сейсмогеологический разрез по композитному профилю M07+811801+130203.

Рис. 9. Схема фациального районирования кембрийских отложений (ботомский ярус) по результатам глубокого бурения и интерпретации сейсмических данных. Условные обозначения: 1 - крупные выступы фундамента (зоны отсутствия кембрия); 2 - зона отсутствия иниканской свиты, установленная по сейсмическим данным; 3-6 - фации солеродного бассейна: 3 - вскрытые скважинами, 4 - прогнозируемые по сейсмическим данным, 5 - установленного распространения по результатам глубокого бурения и сейсмическим данным, 6 - предполагаемого распространения; 7-10 - фации барьернорифового комплекса: 7 - вскрытые скважинами, 8 - установленные по сейсмическим данным, 9 - установленного распространения по результатам глубокого бурения и сейсмическим данным, 10 - предполагаемого распространения; 11-15 - фации открытого бассейна: 11 - вскрытые скважинами, 12 - установленные по сейсмическим данным, 13 прогнозируемые по сейсмическим данным, 14 - установленного распространения по результатам глубокого бурения и сейсмическим данным, 15 - предполагаемого распространения; 16 - аномалии волнового поля типа «массивное тело». Сокращенные названия свит и толщ: СК - синско-куторгиновая, Уд - удачнинская, Ол - олекминская, Км - кумахская. Сокращенные названия скважин: см. рис. 1.

Рис. 10. Схема фациального районирования кембрийских отложений (тойонский, амгинский, низы майского ярусов) по результатам глубокого бурения и интерпретации сейсмических данных (Условные обозначения: см. рис. 9. Сокращенные названия свит и толщ: М - метергерская, И - ичерская, Ч - чарская, ВИ - водорослевых известняков).

Рис. 11. Схема фациального районирования кембрийских отложений (середина майского яруса) по результатам глубокого бурения и интерпретации сейсмических данных (Условные обозначения: 1 - зоны отсутствия отложений среднего и верхнего кембрия, установленные по сейсмическим и скважинным данным; 2-6 - свиты майского яруса: 2 вскрытые скважинами, 3-4 - прогнозируемые по результатам сейсмофациального анализа (косослоистый, клиноформный рисунок сейсмозаписи: 3 - уверенный, 4 - менее уверенный), 5 - установленного распространения по результатам глубокого бурения и 
сейсмическим данным, 6 - предполагаемого распространения; 7-8 - фации чукукского (?) рифового комплекса. Остальные усл. обозн.: см. рис. 9. Сокращенные названия свит и толщ: О - оленекская, Дж - джахтарская, Сл - силигирская, Мл - малыкайская, Хб хабардинская, Чк - чукукская, Зл - зеленоцветная, Бр - бордонская, Бп - баппагайская, УБ - усть-ботомская, УМ - усть-майская, Ч - чайская). 


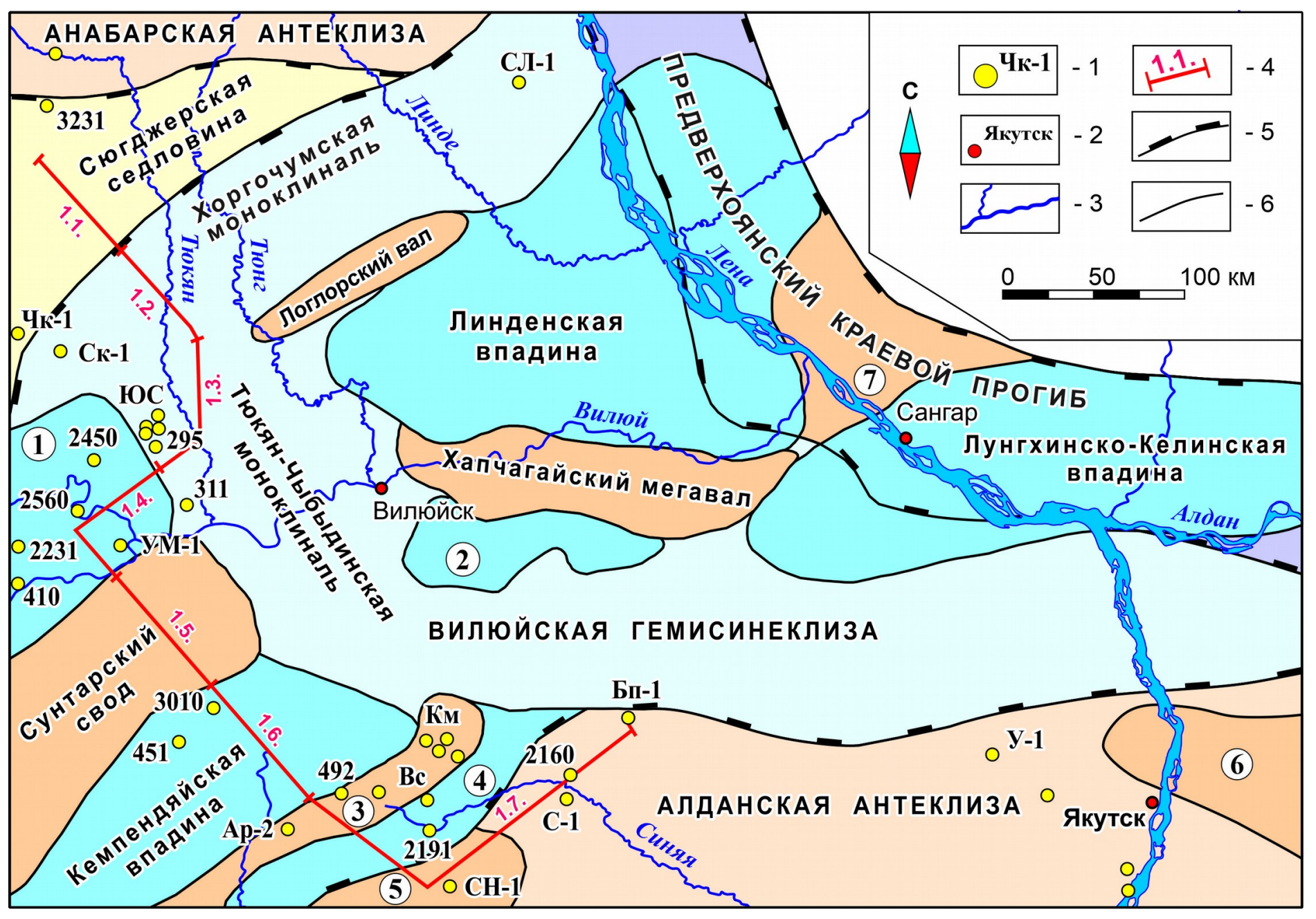



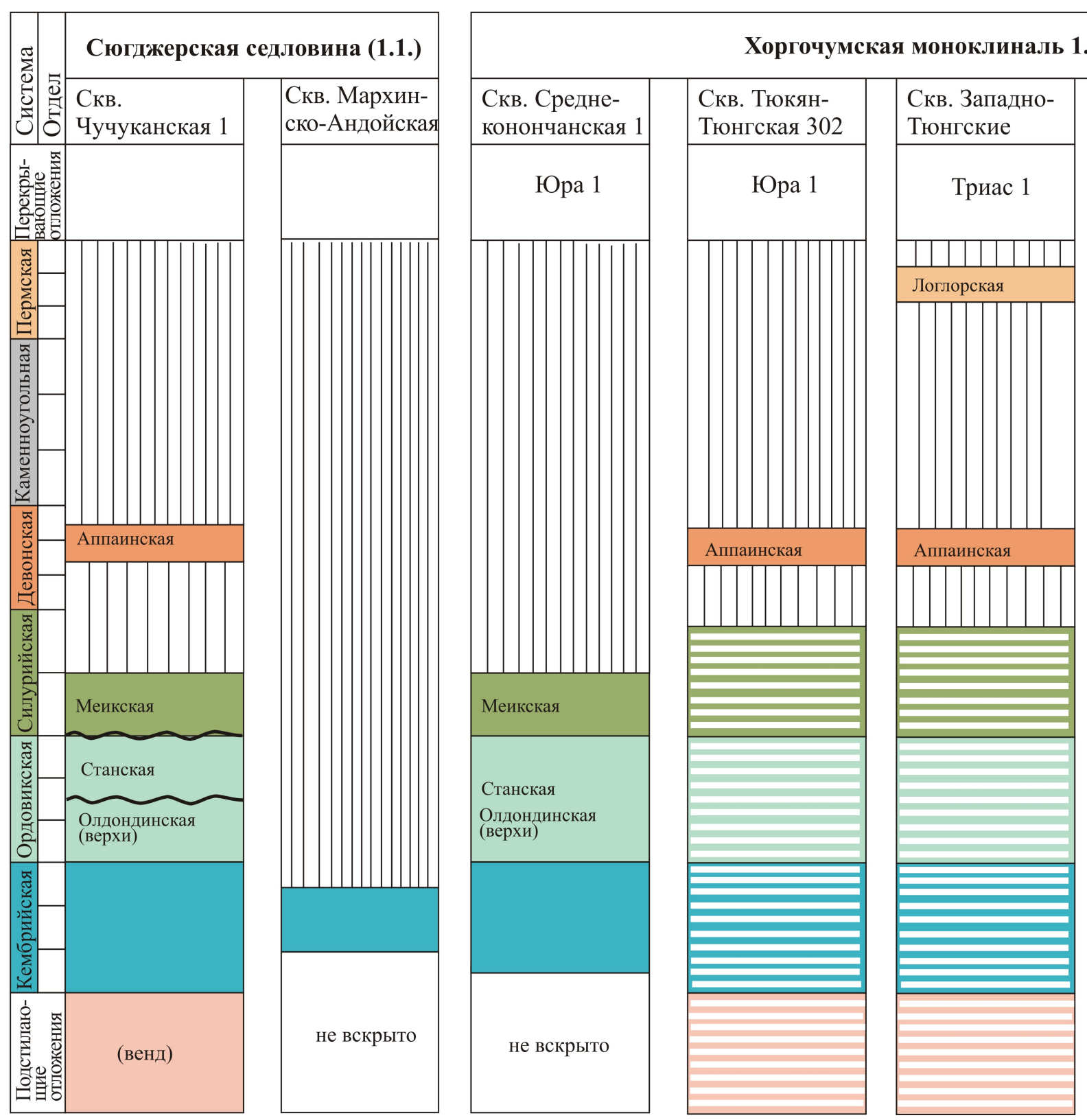

Скв. Средне-

Скв. Мархин-

ско-Андойская

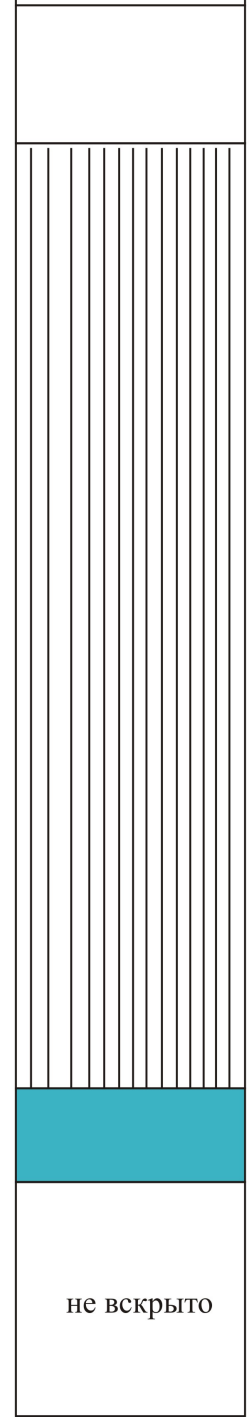

Тюнгская 228

Триас 1

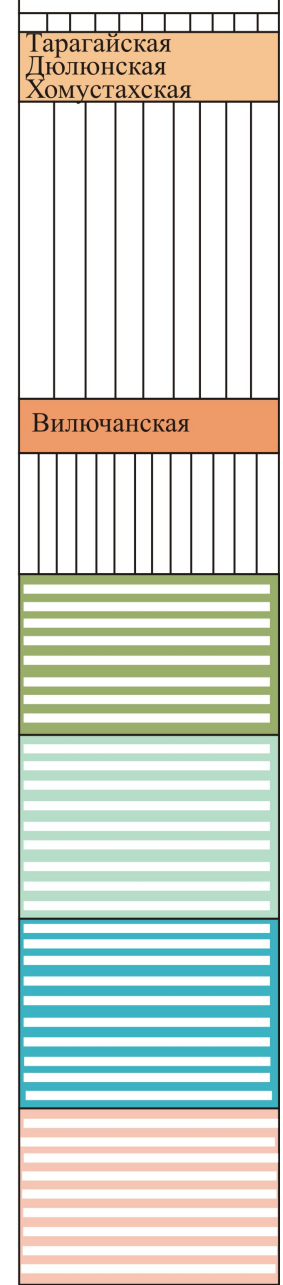




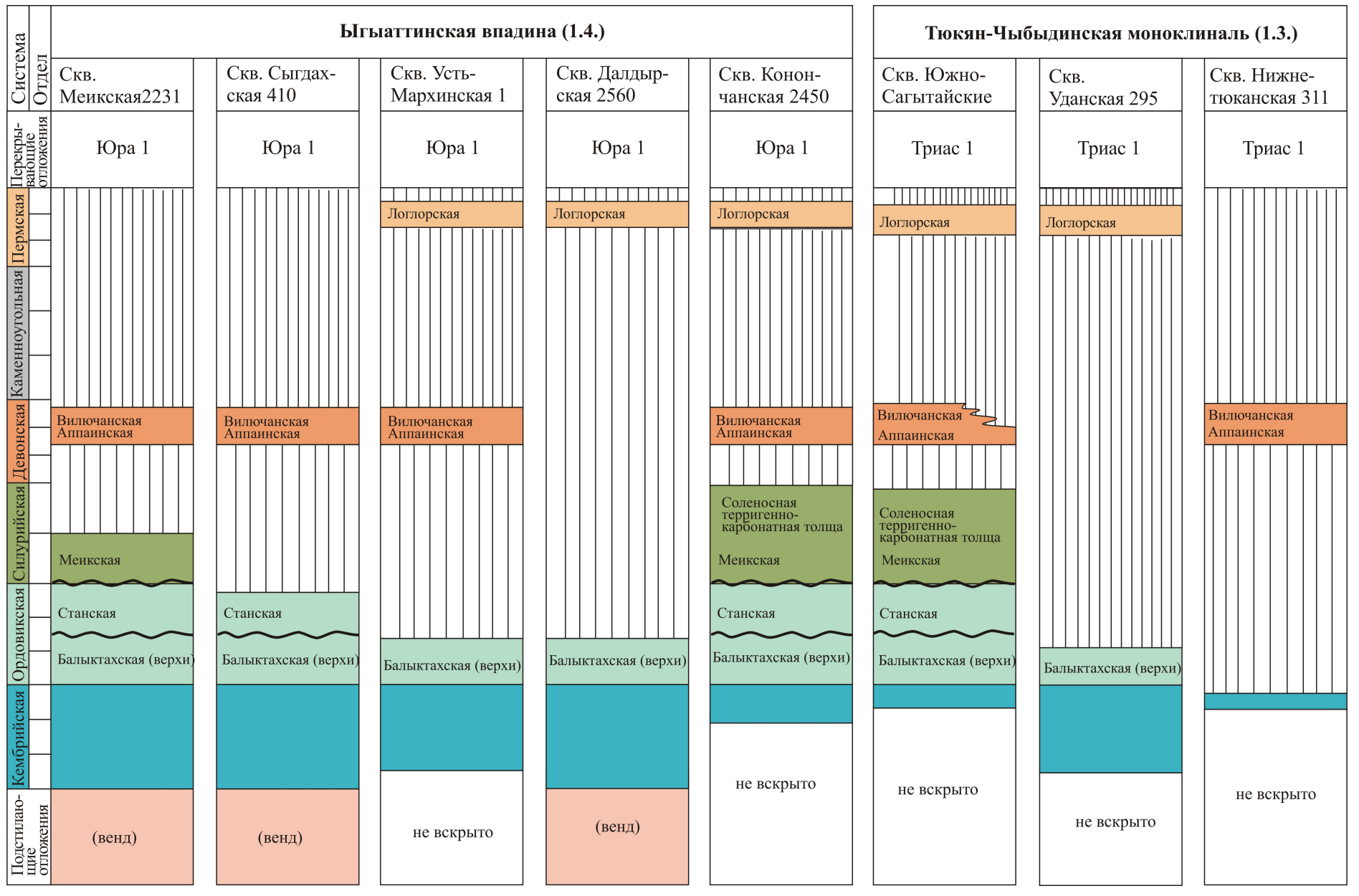




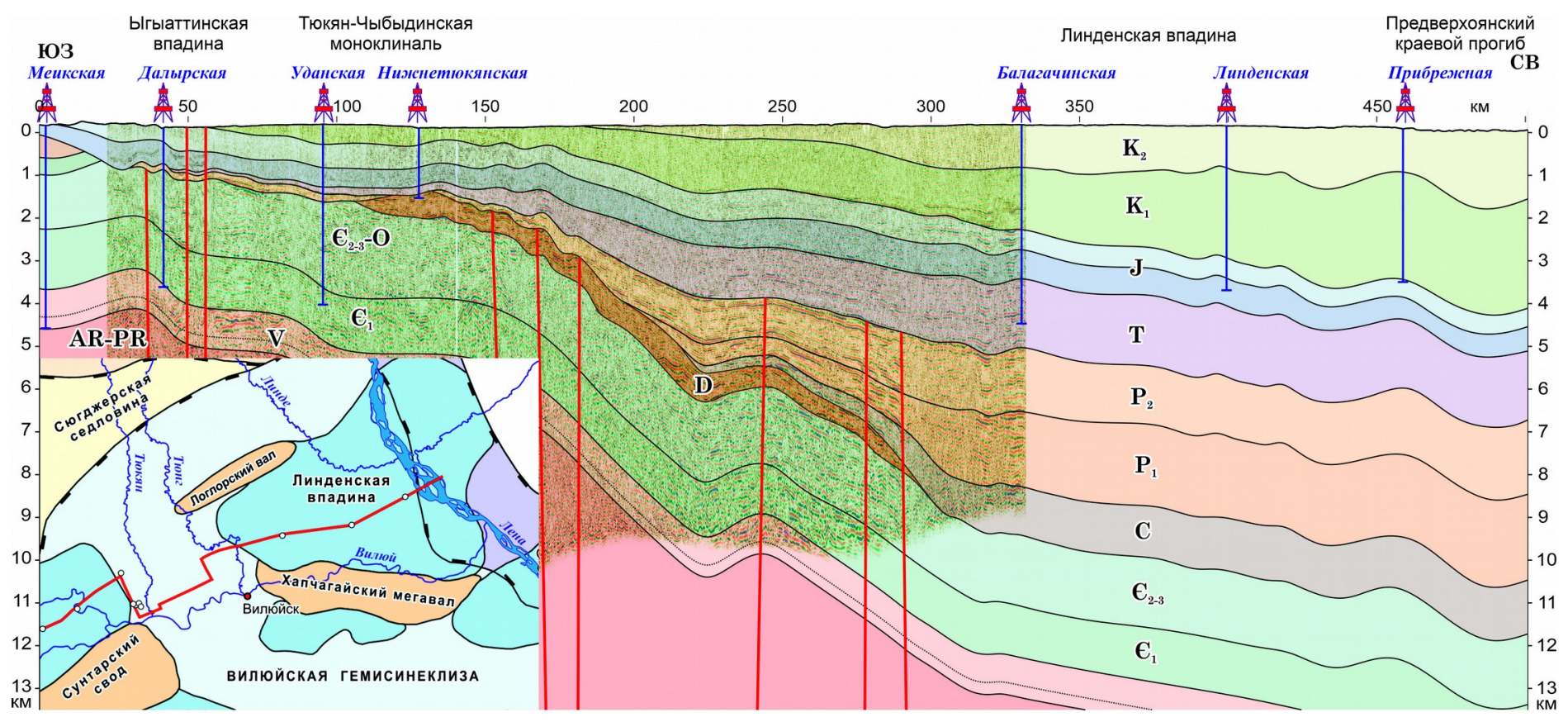




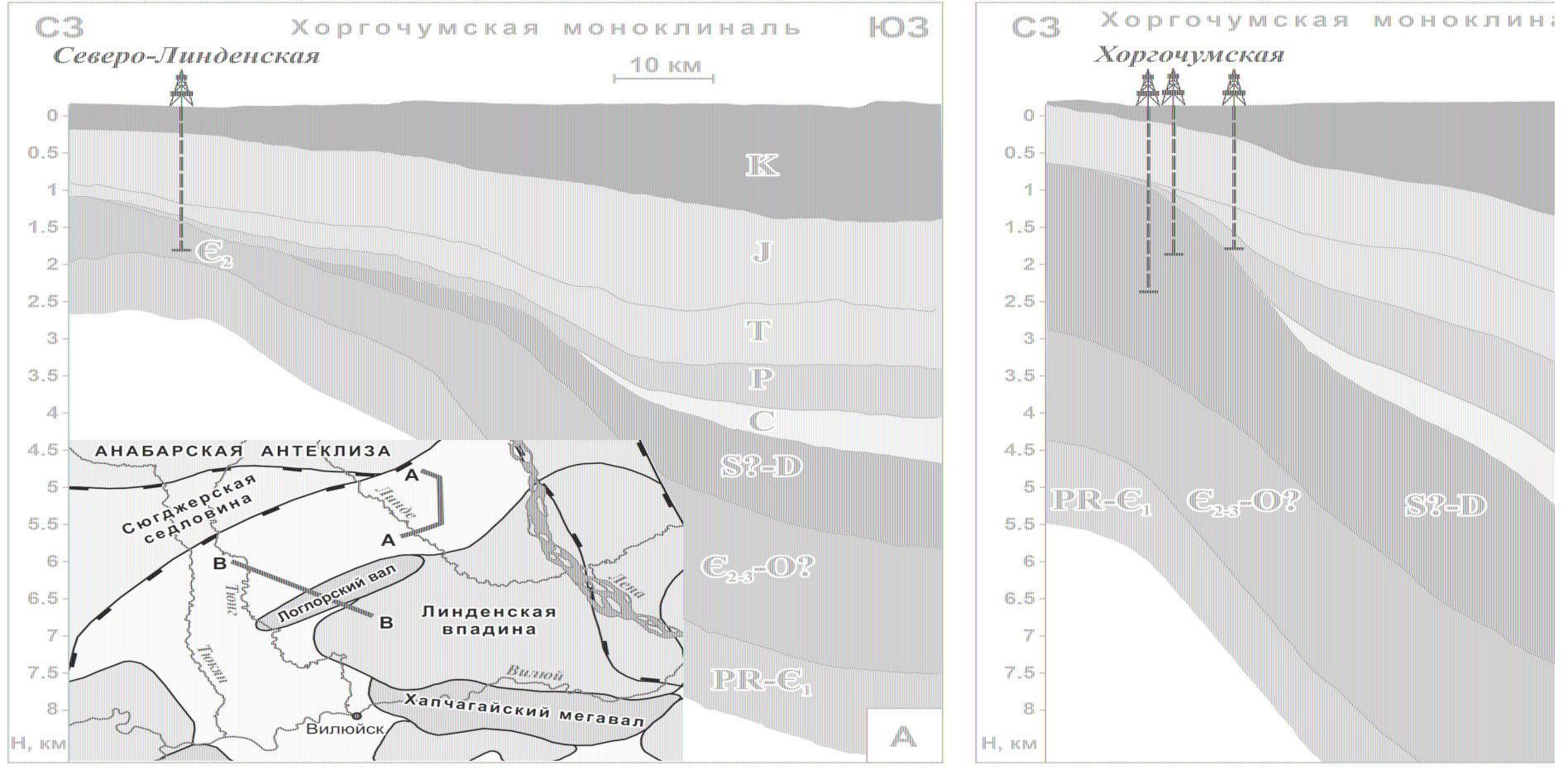




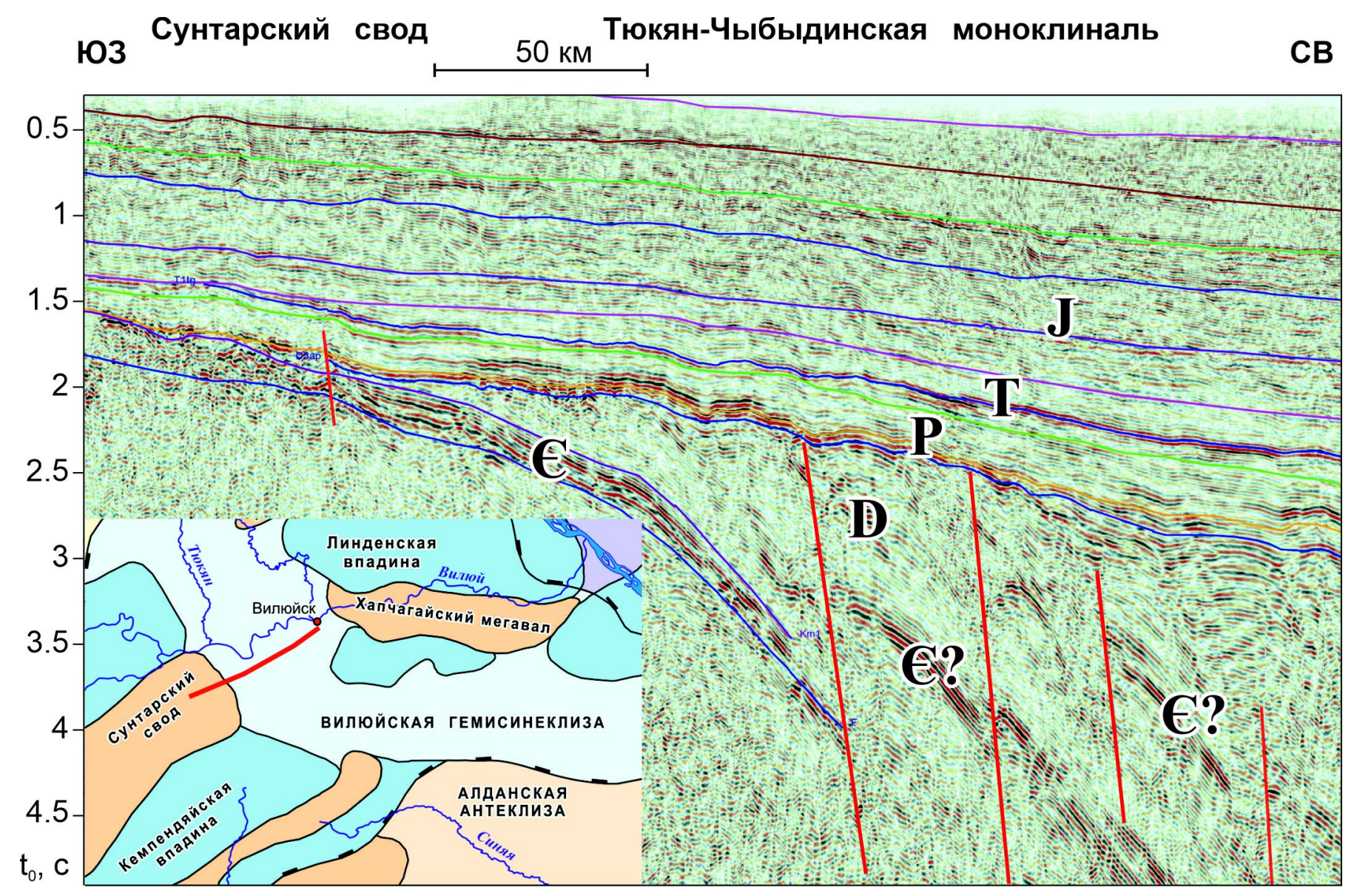


номер на профиле 1.7.
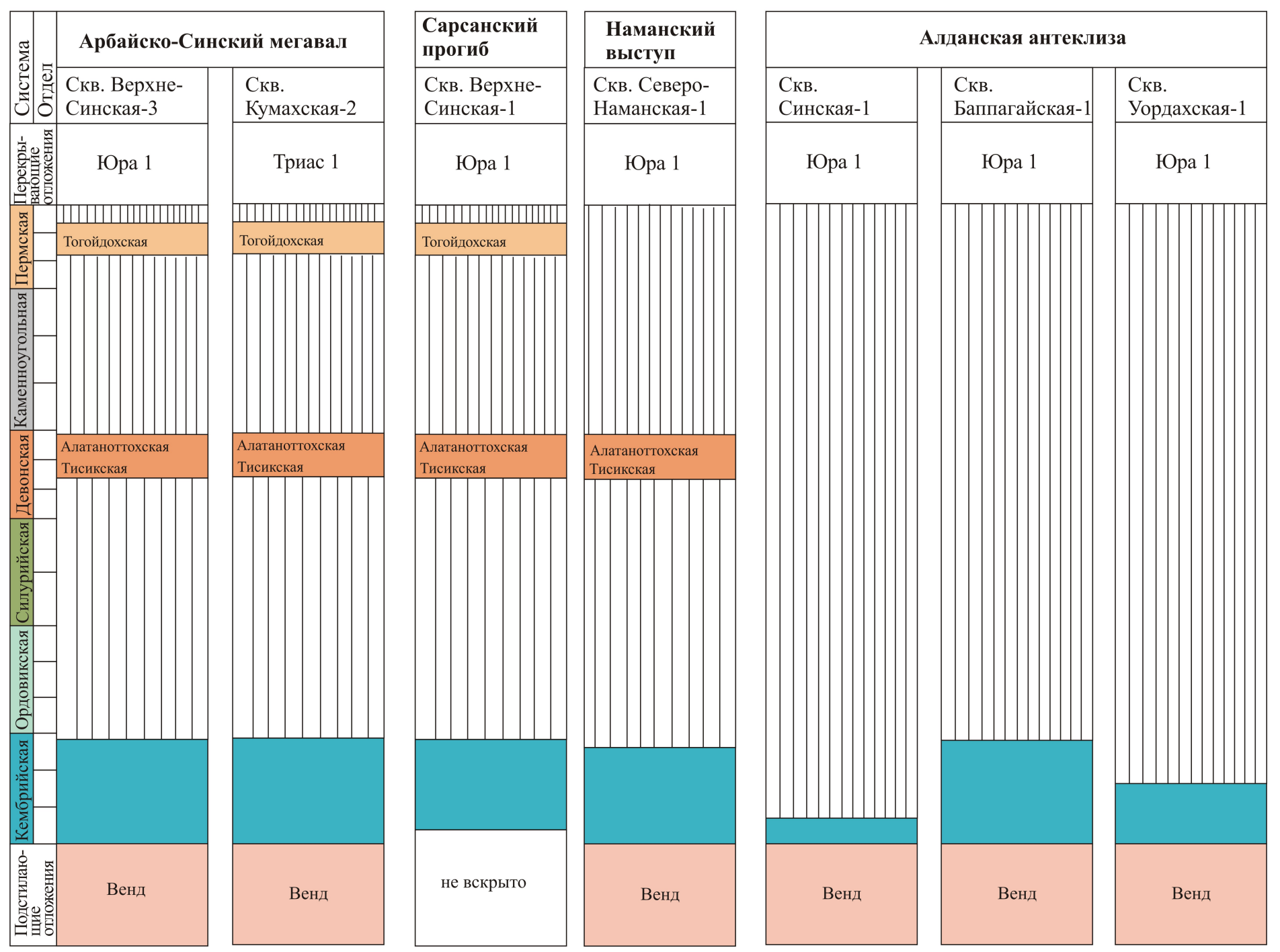


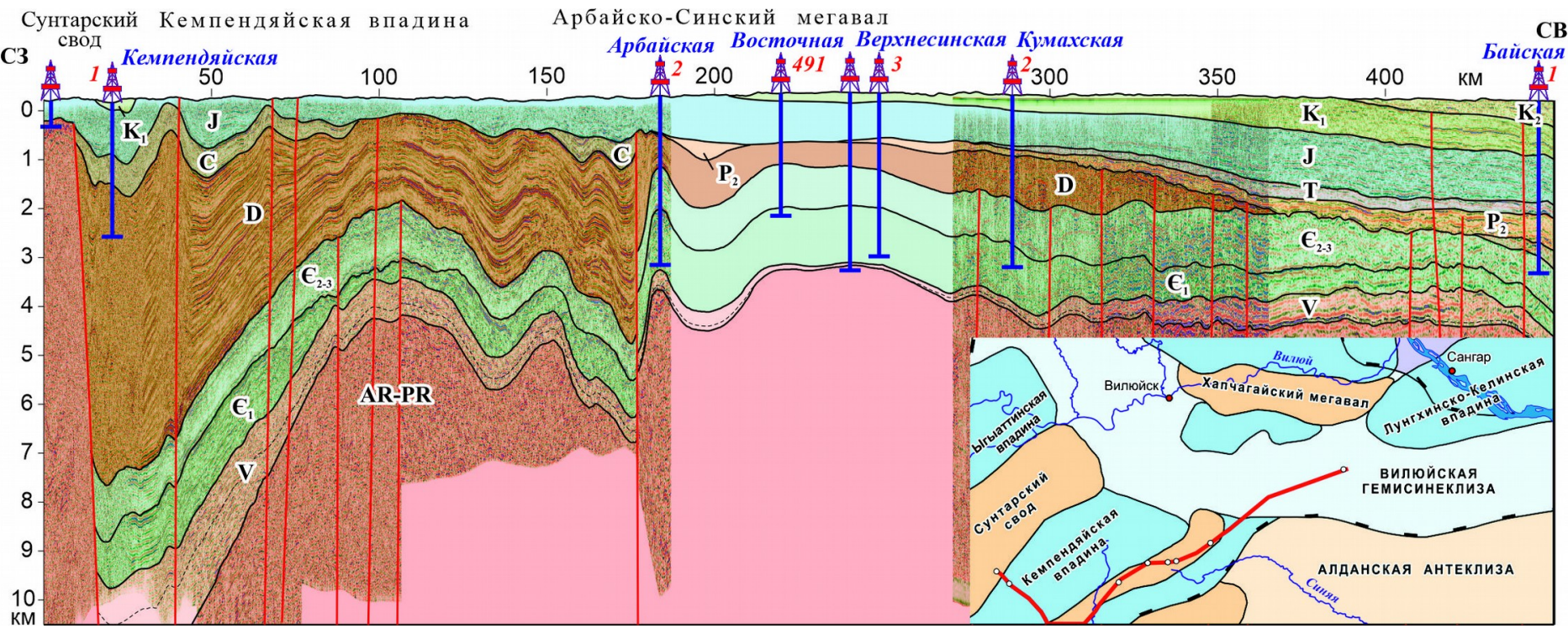




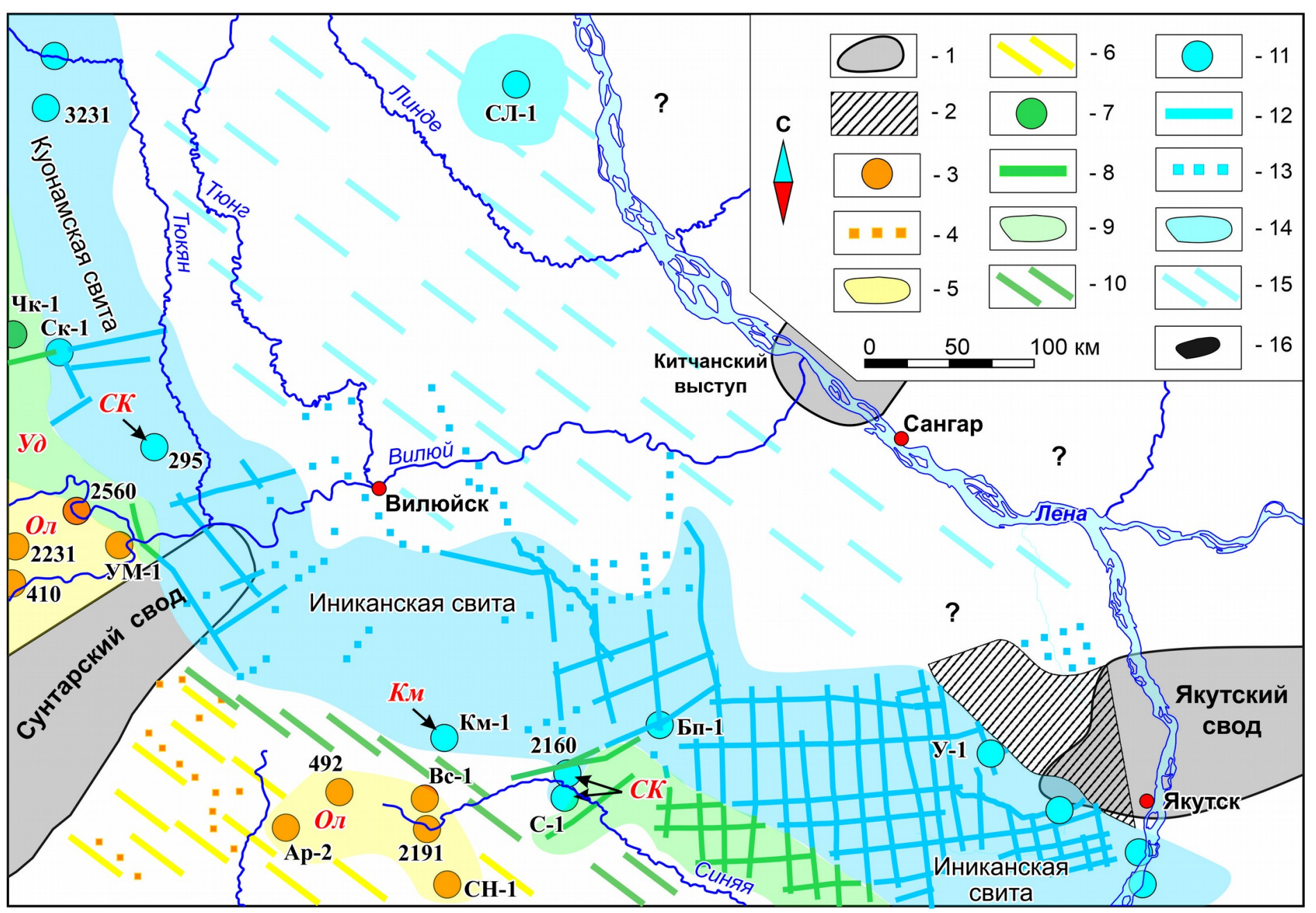




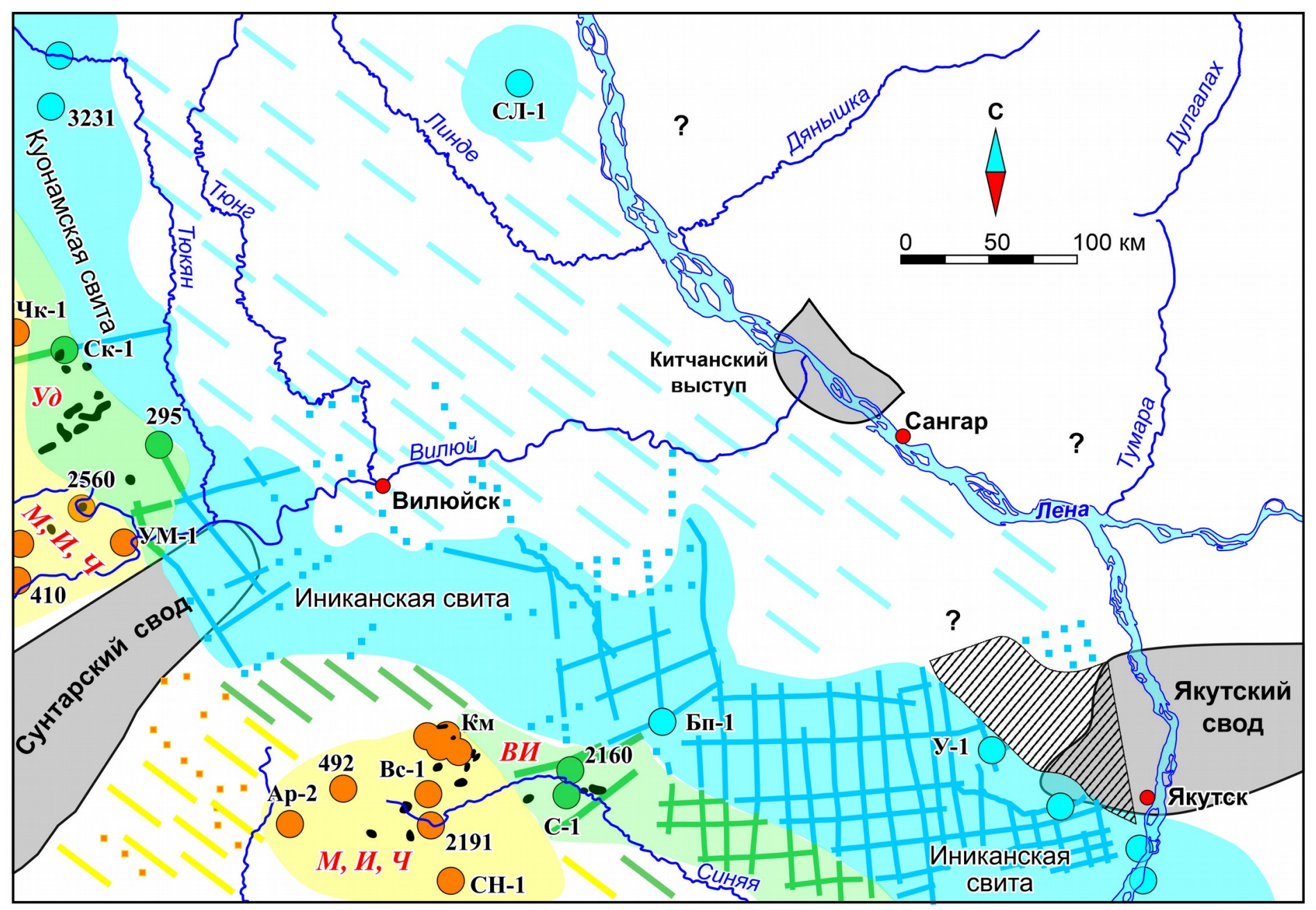




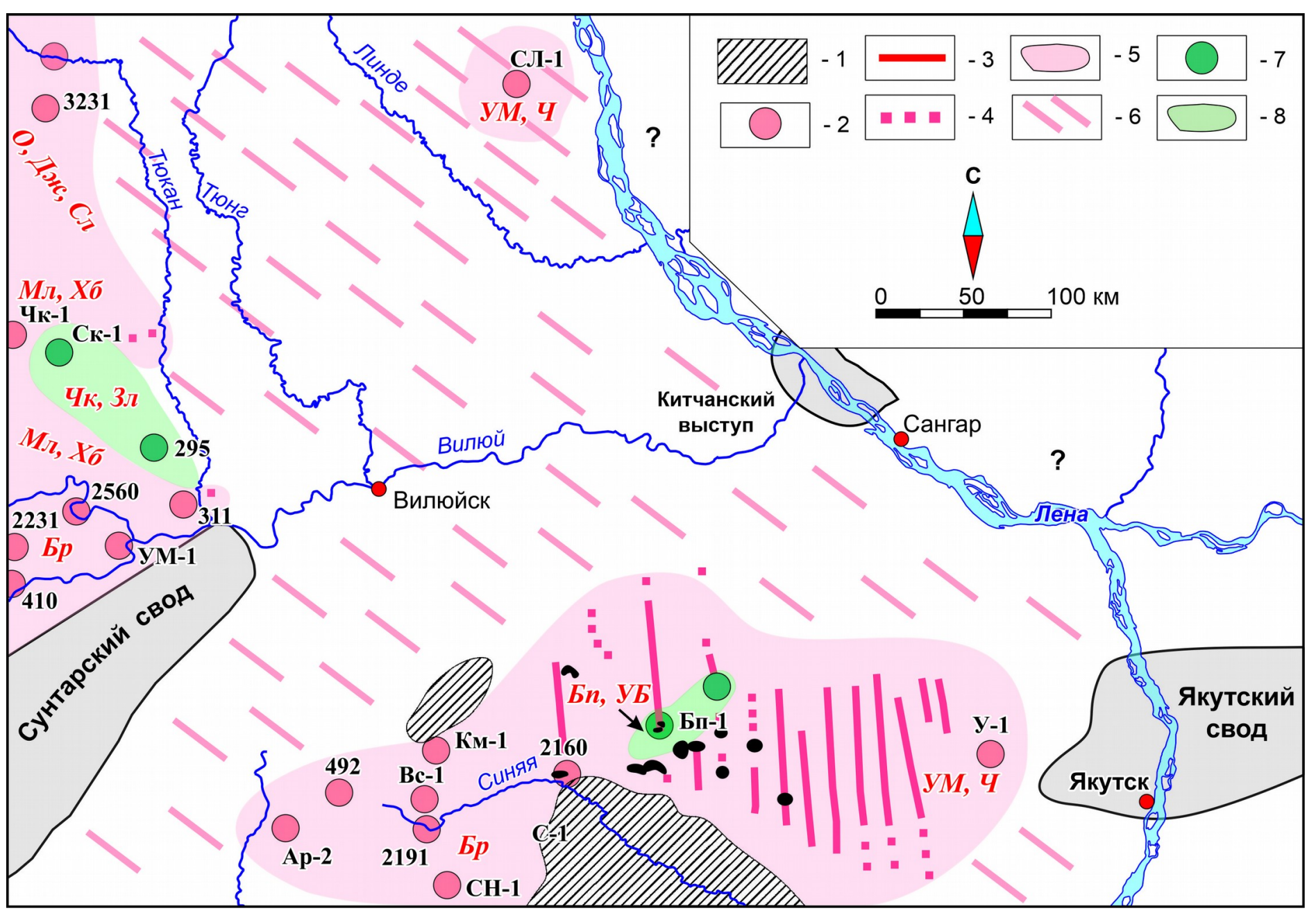

